\title{
Publisher Correction to: Financial innovation, volume 5
}

Financial Innovation

Correspondence: info@ biomedcentral.com

London, UK

\section{Publisher Correction to: Financial innovation, volume 5}

An error occurred during the publication of a number of articles in Financial Innovation. Several articles were published in volume 5 with a duplicate citation number.

In this correction article the old and new citation metadata are published in Table 1.

The original articles have been updated. The publisher apologizes for the inconvenience caused to our authors and readers.

Table 1 Overview of incorrect and correct citation metadata

\begin{tabular}{lll}
\hline DOI & Incorrect citation number & Correct citation number \\
\hline $10.1186 /$ s40854-019-0140-6 & 1 & 26 \\
$10.1186 /$ s40854-019-0141-5 & 2 & 23 \\
$10.1186 /$ s40854-019-0135-3 & 3 & 22 \\
$10.1186 /$ s40854-019-0138-0 & 4 & 24 \\
$10.1186 / s 40854-019-0139-z$ & 5 & 25 \\
\hline
\end{tabular}

Published online: 28 August 2019 